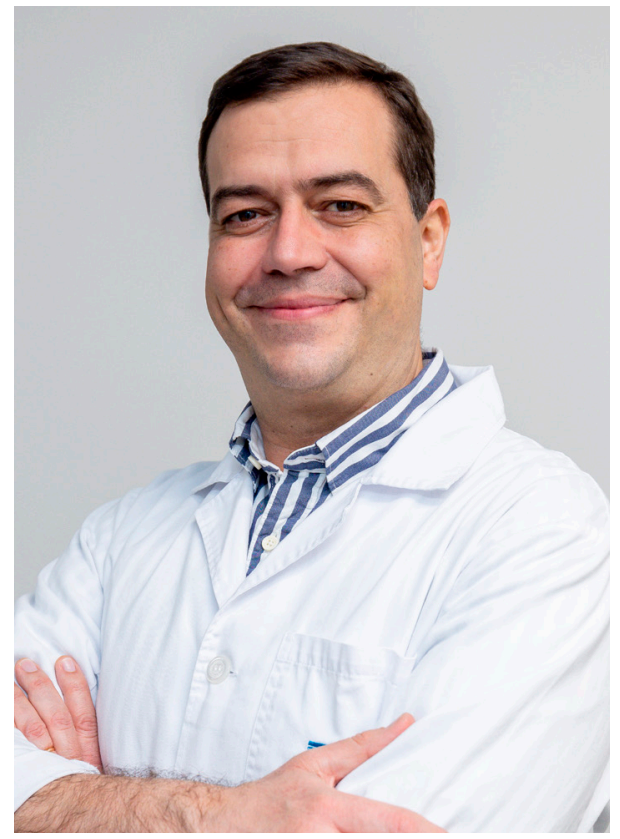

\title{
Simulação Clínica: Formação e Inovação na Promoção da Qualidade e Segurança do Doente
}

\author{
Clinical Simulation: Training \\ and Innovation to Promote Quality \\ and Patient Safety
}

Pedro Garcia ${ }^{1}$

O ensino clínico está a mudar.

O velho paradigma "see one, do one, teach one" está desatualizado e é hoje em dia considerado eticamente questionável. Métodos tradicionais de ensino, baseados em exposição teórica, e avaliação baseada em testes escritos, não são suficientes para garantir a aquisição de conhecimentos e competências, essenciais à promoção da qualidade e segurança do doente.

A Simulação, assume assim um papel fundamental no preenchimento destas lacunas, desde o ensino pré-graduado ao treino clínico pós-graduado ultra diferenciado.

A Simulação aplicada à Medicina define-se como uma ferramenta de ensino e treino clínico, que através da utilização e modelação de dispositivos, técnicas, atitudes e meio ambiente, mimetiza uma tarefa ou um aspeto de cuidados assistenciais, que permite o treino de forma replicável, realista e adequado à prática clínica.

Desta forma, a Simulação tem um campo de ação muito lato e uma ampla variedade de conceitos, programas e modelos disponíveis:

- Modelos de treino de técnicas isoladas

- Simuladores de baixa fidelidade

- Simuladores de alta-fidelidade

- Simulação baseada em software

- Simulação com recurso à utilização de produtos de origem animal inerte e cadáveres humanos

- Simulação com utilização de doentes standardizados

- Realidade virtual 
- Realidade "Aumentada" (conceito mais recente que se define como: visão direta ou indireta de um ambiente físico, real, cujos elementos são "aumentados" por elementos sensoriais gerados por computador ou extraídos do mundo real, como som, vídeo, gráficos ou sensação táctil).

O ensino e treino baseado em simulação, implica uma formação específica nesta área, bem como o domínio dos aspetos pedagógicos que lhe estão associados.

A adaptação dos programas simulação ao grau de diferenciação dos formandos (pré-graduado versus pós-graduado) e às necessidades formativas (competências técnicas versus não técnicas) é de extrema importância para a construção de bons programas de formação.

A construção de cenários clínicos realistas, a definição de objetivos de aprendizagem bem definidos, a possibilidade de treino de equipas multidisciplinares e a aplicação de métodos de debriefing estruturados, são elementos fundamentais na obtenção e retenção de conhecimentos e atitudes clínicas.

Por outro lado, a aquisição de competências técnicas e proficiência clínica num determinado procedimento, depende da estruturação de uma curva de aprendizagem individual com horas de treino específicas.

Consciente desta realidade e em alinhamento com valores, como a inovação, o desenvolvimento humano e a competência clínica, a CUF desenhou e estruturou um projeto sólido de ensino e treino baseado em Simulação em parceria com a NOVA Medical School e inaugurou em 2020 o Centro de Simulação CUF Academic Center, capaz de dar resposta a todas as áreas formativas com recurso a ambientes e técnicas simuladas, em ambiente pré e pós-graduado.

O Centro de Simulação CUF Academic Center tem como missão garantir a promoção da segurança do doente, qualidade clínica assistencial e formação contínua dos profissionais da CUF através da utilização de tecnologias de simulação avançada integradas com a excelência do seu corpo clínico e docente.

A era que vivemos, condicionada pela pandemia por SARS-CoV-2, definiu limitações de acesso ao doente e por vezes até à formação e formadores nas mais variadas áreas clínicas.

Desafiados por esta nova realidade e necessidade de inovação formativa, o Centro de Simulação CUF Academic Center e a sua equipa pedagógica, estruturaram um programa de formação e treino clínico, baseado nos princípios de Prática Deliberada aplicada à Medicina, denominado "Ginásio de Simulação CUF".

O conceito de "Ginásio de Simulação" assenta numa base de sustentação teórica estruturada em 4 pilares essenciais para o treino e aquisição de competências clínicas:

1 - Equipamento (simuladores realistas e equipamento de uso clínico assistencial diário)

2 - Formadores (responsáveis pelo programa de formação, fidelidade e feedback ao formando)

3 - Horas de treino (programa estruturado, baseado em etapas sequenciais e tempo médio de treino para cada técnica, adaptado individualmente a cada formando)

4 - Avaliação (baseada em escala validada).

Através deste programa, os formandos podem treinar em formato de tutoria contextualizada no seguimento de um curso, no formato de tutoria personalizada através de tarefas standardizadas previamente validadas, ou em formato de treino livre (sem tutoria) que implica um grau de diferenciação avançado por parte do trainee (p. ex. treino experimental baseado em simulação de uma técnica específica). 
A Simulação é uma ferramenta de aquisição de competências clínicas (técnicas e não técnicas) eficaz, mas necessita de uma equipa de instrutores com formação específica.

O Centro de Simulação CUF Academic Center tem desenvolvido um programa de formação de formadores em parceria com a SPSim - Sociedade Portuguesa de Simulação Aplicada às Ciências da Saúde e com a AHED - Advanced Health Education, e dispõe neste momento de uma equipa pedagógica com formação específica nesta área.

A Simulação está implantada no ensino e treino da Medicina, da Enfermagem, dos Técnicos, dos Assistentes, das Equipas Hospitalares e de Assistência Primária.

Os Centros de Simulação devem estar em articulação direta com os Departamentos de Qualidade e Segurança do Doente, com as Comissões de Ética, de Farmácia, de Ensino e de Gestão Hospitalar.

Este posicionamento central ao serviço de entidades internas e externas, tem resultados comprovados com translação à clínica assistencial diária, e ganhos não quantificáveis não negligenciáveis.

Ao longo de 2 curtos anos de existência, num contexto desafiante de pandemia por SARS-Cov-2, o Centro de Simulação CUF Academic Center estabeleceu parcerias com Faculdades de Medicina, Sociedades Científicas, Associações de Estudantes, Indústria Farmacêutica e de Dispositivos, Laboratórios de Experimentação e Investigação, Federações Desportivas e outros Centros de Simulação nacionais e internacionais, assumindo um papel de responsabilidade, inovação, vanguarda e força motriz na formação clínica em Portugal.

A caminho da certificação ... este é o DNA do Centro de Simulação CUF Academic Center. 